\title{
Making Sense of the Past: the Embodied Information Practices of Field Archaeologists
}

Journal of Information Science I-II

(C) The Author(s) 2015

Reprints and permissions: sagepub.co.uk/journalsPermissions.nav DOI: 10.1 I77/0165551510000000 jis.sagepub.com

\author{
Michael Olsson \\ Department of Communication, University of Technology Sydney, Australia
}

\begin{abstract}
This paper reports the findings of a study of the information practices of archaeologists, students and volunteers undertaking an excavation in the field. Conceptually, the study was guided by a social constructionist and practice-theoretical epistemological standpoint. Methodologically, the study employed a multi-faceted approach incorporating both ethnographic observation of archaeologists working in the field and in-depth interviews. The findings show that participants' practices were both social and embodied in nature.
\end{abstract}

\section{Keywords}

Author keywords; Information practices; embodied information practices; ethnography; Sense-Making

\section{Introduction}

This article reports the findings of a study of the information practices [1] of archaeologists, students and volunteers undertaking an excavation in the field. It focuses in particular on those practices by which participants made sense of the artefacts they uncovered, and through these, the site they were excavating. The findings show that these practices were both social and embodied in nature.

The study is based on fieldwork carried out at two sites: the Iron Age Broch of Gurness and Neolithic Ness of Brodgar excavations in Orkney, Scotland, through the course of two digging seasons in 2013 and 2014. Both of these sites are being excavated under the auspices of the Orkney Research Centre for Archaeology (ORCA $)^{1}$ of the University of the Highlands and Islands in Scotland. The Broch of Gurness site ${ }^{2}$ on the island of South Ronaldsay is an Iron Age Pictish site featuring the broch itself (a fortified tower), a souterrain (an underground building) and a range of associated dwellings and industrial structures. The Ness of Brodgar ${ }^{3}$ is a Neolithic ritual site covering more than 2.5 hectares (6.2 acres), positioned between the Neolithic stone circles, the Stones of Stennes and the Ring of Brodgar. It is at the centre of the Heart of Neolithic Orkney World Heritage site, and is widely regarded as one of the most important archaeological excavations being undertaken in Europe at the present time. It has also been the subject of considerable public and media interest, having been included in at least four television programs, as well as having a cover story in National Geographic ${ }^{4}$. Thousands of visitors are attracted to the site during the excavation season.

An important feature that connects these sites is that each is the product of a non-literate culture. This means that archaeologists working in these contexts do not have access to contemporary texts to assist them in making sense of their discoveries. Somewhat counterintuitively, Pryor [2] suggests that this leads to a more rigorous scholarship amongst prehistoric archaeologists, arguing that historical archaeologists' interpretations of sites are too dependent on contemporary written sources.

The nature of physical objects as information has been a focus of theorising in our field from its beginnings. As Lund [3] points out, the pioneering documentalist Paul Otlet argued that physical objects can be informative, and therefore are 'documents'. Suzanne Briet [4] took this further, arguing that academic enquiry and classification are among the factors that transform an object into a document.

\section{Corresponding author:}

Michael Olsson, University of Technology Sydney, Australia

Michael.Olsson@uts.edu.au 
Before an artefact can be displayed in a museum, or even classified for inclusion in an archaeological repository, it must not only be unearthed, but also identified as an artefact. The same is true of archaeological sites themselves. The Ness of Brodgar, for example, although now recognised as one of the most important Neolithic sites in Europe, was considered a natural hill formation until a 2003 geophysical survey of the area. The present study might therefore be seen as a case study of the social practices by which objects and places become 'documents'. Although having a similar conceptual approach to Huvilla's [5] work on archaeological reports as boundary objects, this study has a different focus. While archaeological reports can be seen as the end product of an archaeological excavation, the present study focuses instead on the information practices of archaeologists, students and volunteers whilst in the field - the beginning of the archaeological sense-making process.

\section{Conceptual Framework}

The present study should be seen as part of the emerging 'information practice' umbrella discourse described by Savolainen [1]. This discourse emerged in the first decade of the twenty-first century as a critical alternative to the 'information behaviour', which focuses on the individual information seeker. Savolainen follows Talja in suggesting that the key characteristic of this new discourse is that it represents "a more sociologically and contextually oriented line of research" which: ...shifts the focus away from the behavior, action, motives and skills of monological individuals. Instead the main attention is
directed to them as members of various groups and communities that constitute the context of their mundane activities. [1,p. 120]

The study was guided by a social constructionist [6] and practice-theoretical epistemological perspective [7][8]

Knowledge is not what resides in a person's head or in books or in data banks. To know is to be capable of participating with the requisite competence in the complex web of relationships among people, material artifacts and activities.... On this definition it follows that knowing in practice is always a practical accomplishment. [9, p. 517]

This is based on the understanding that field archaeology is a domain where specific socially constructed understandings prevail over others, imbued with particular values and norms that shape the participants' practical accomplishment of their archaeological practice. Conceptually, the study was also influenced by a range of other theoretical frameworks including Dervin's Sense-Making [10], Foucauldian [11] and critical discourse analysis [12].

Dervin's approach to Sense-Making was important to the study because of its emphasis on developing a holistic understanding of how individuals and communities make sense:

...embodied in materiality and soaring across time-space ... a body-mind-heart-spirit living in time-space, moving from a past, in a present, to a future, anchored in material conditions; yet at the same time with an assumed capacity to sense-make abstractions, dreams, memories, plans, ambitions, fantasies, stories pretences that can both transcend time space and last beyond specific moments of time space. [13, p. 730]

Dervin's work complemented practice theory in drawing attention to the affective, as well as the embodied nature of the participants' sense-making practices.

Similarly, the Foucauldian and critical discourse analytical traditions offered the researcher important conceptual tools for understanding that participants' discussions with the researcher and with each other took place in the broader context of an existing network of discursive power/knowledge relations.

The study's interest in the embodied nature of participants' information practices grew in part out of the researcher's previous work with theatre professionals [14][15][16]. One motivation behind the present study was to explore the role of embodied information practices in an academic rather than artistic environment. Another key influence on the research's conceptualisation of embodiment was Coupland and Gwynn's work on discourse, the body and identity [17]. The present study also owes an enormous debt to Lloyd's ground-breaking studies of the embodied information practices of firefighters [18] and nurses [19].

\section{Methodology}

Methodologically, the study employed a multi-faceted approach incorporating both ethnographic observation of archaeologists working in the field [20][21] and in-depth interviews with ten archaeologists and archaeology students 
associated with the two digs. At the beginning of the ethnographic fieldwork, the researcher endeavoured to take written notes, but this was soon abandoned. Firstly, the physical environment made this approach impractical and secondly, the researcher observed that note-taking made the observation more visible, making participants self-conscious. Instead, audio notes were made using a small digital voice recorder. This recorder also had the advantage of allowing the researcher to carry out informal, on-the-spot interviews with team members. The longer interviews took place away from dig sites, usually in the participant's office. The researcher used an interview guide incorporating elements of Dervin's Sense-Making methodology [10], although the overall approach was heavily influenced by Seidman's [22] less structured, more conversational approach to research interviewing. Interviews lasted from 45 to 90 minutes and were digitally recorded.

All of the interviews and the researcher's audio field notes were then transcribed to facilitate analysis. The data was analysed using an inductive approach based on a constant comparison approach [23]. Although the analysis was informed by a range of theoretical perspectives, including Sense-Making, critical discourse analysis and practice theory, the study's aim was not to test a pre-defined theory or hypothesis, but to develop a contextual, situated understanding of the relationship between participants' context, their role/s as members of the dig team and the broader archaeological community, the discourses they engaged with and their information practices. The research used follow-up interviews and email correspondence with participants to discuss emerging findings, check potential biases and explore rival explanations [24]. Participants thus played an active role in the co-construction of findings and helped to increase the validity of the researcher's analysis. Participants' involvement in the analysis process was informed by Dervin's view of the actor as:

....an expert in her world (e.g. in her body, her work, her life) ... Sense-Making assumes the actor as theorist of her world, with hunches, hypotheses, and generalizations about how things connect to things and how power flows. [13, p. 740]

A key assumption underpinning the analysis process was that "social reality is produced and made real through discourses, and social interactions cannot be meaningfully understood without reference to the discourses that give them meaning" [25, p. 3]. Thus, our analyses focused on how the participants' statements could be understood as 'truth claims' in relation to broader discourses that governed the participants' shared domain of practice. In keeping with the critical tradition in discourse analysis, this involved examining the way in which particular discursive statements are interrelated within a broader socio-cultural and political "order of discourse" [12]. The study's approach resembled most closely what Alvesson and Kärreman have termed a meso-discourse approach, i.e. "being relatively sensitive to language use in context but interested in finding broader patterns and going beyond the details of the text and generalizing to similar local contexts." [26, p. 1133].

\section{Findings}

The research's findings show that the archaeological teams studied possessed information cultures that were both complex and highly effective. The present article focuses particular attention on those findings related to embodied information practices but it should be noted that both dig sites also provided evidence of being discursively rich environments. As in the author's previous research [15], the findings also demonstrated that affective factors also played an important role in facilitating information sharing practices.

\section{I. Personal Expertise}

Contrary perhaps to the preconceptions of traditional information seeking researchers, the study's findings show that reference works, whether printed or electronic, play almost no role in this initial identification process.

There'll be plenty of time to consult the literature later - back at the department, during conservation. That's the time to do your detailed analysis. But that's just not practical out here in the trenches. Here what we need is a preliminary identification of what we're dealing with, $\left(\mathrm{Lugh}^{5}\right.$, site director)

Instead, this key decision - the beginning of an object's transformation into a document - was based almost exclusively on the expertise of members of the dig team, with students and volunteers calling on the expertise of an experienced team leader who in turn could, if they deemed it necessary, call in turn on the expertise of various finds experts and/or the site director. 
Sometimes working out what you have - even if you have something or not - is really hard! Most finds are small and in the ground they don't look anything like they do in the textbooks. ... They tell us if we're not sure, we should ask our trench supervisor. It's pretty amazing how Thor [trench supervisor] and Macbeth [finds expert] can look at something still in the ground and tell you what it is. (Guinevere, student)

Temporal and Environmental factors clearly contribute to the preference for personal expertise:

Well we are in Scotland! Rain and mud aren't where you want to pull out your iPad! (Gawain, trench supervisor) I can't have the whole team standing around while I go off to look something up! If I'm not sure, I'll give Macbeth [finds expert] a shout and I can always call over Lugh [site director] or Morrigan [finds expert] for a second opinion. (Icarus, trench supervisor)

However, it would be a mistake to see this preference as simple expediency:

The expertise that we have here on-site is quite extraordinary. We have experts in pottery, flint, stone tools, animal bones... You can't beat having a set of expert eyes look at what you've found. They can tell you what you might have and what else to look out for. Macbeth [finds expert] can look at a small bit of pottery and tell you it's from a storage jar or a bowl, what size and shape it was. (Sif, student)

The researcher's observations included many occasions when team members demonstrated the ability to make sophisticated, highly nuanced interpretations of even fragmentary finds, such as pottery shards or flint flakes:

It takes a really expert eye to look at a stone and be able to see that the marks on it are signs of wear - that it's been used as a stone tool ... Someone thousands of years ago picked it up and used it... (Beowulf, trench supervisor)

Furthermore, team members showed the ability to develop sophisticated and nuanced understandings of the sites based on their ability to interpret quite ephemeral features, such as a colour change in the soil or on a stone surface.

This dark patch of soil indicates more nutrients in the soil ... It's inside one of the structures, so we think they were probably at this period it had become an area for cutting up fish for bait. That fits in with the poor quality of the stonework - lots of dodgy DIY! (Boudicca, site director)

These red circular patches on the rock here are caused by intense heat. They're all that's left of the kilns they used for pottery making. (Macbeth, finds expert)

Each expert brought a range of discursive repertoires, based on their own experience, as well as the literature of the field, to this interpretive process.

I've been doing this for more years than I care to remember! And then you have someone like Freyja. She's doing her PhD looking at incised stone decoration. She probably knows more about that particular topic than anyone in the world. (Macbeth, finds expert)

Participants' accounts make it clear that the preference for personal expertise is not simply a matter of expediency. Rather, by drawing on the personal expertise of other team members, they are not only able to get the information they need more quickly and conveniently than through a formal source, but are also likely to get exactly the information they need.

\section{I. I. Haptic Analysis}

One striking feature of team members' sense-making was the multi-sensory nature of their engagement with potential artefacts. A memorable example of this occurred on the first day of field work. The researcher enquired of a trench supervisor as to why one apparently unremarkable stone was in a finds tray, whilst hundreds of near-identical stones where being placed on the spoil heap. The reply was succinct: "Pick it up!" She went on to explain that its feel in the hand had been a crucial stage in identifying it as a tool.

MacGregor [27] has argued that a multi-sensory approach to the examination of archaeological artefacts can provide insights that visual analysis alone cannot. In particular, he emphasised the importance of haptic analysis for archaeological practice: 
The tactile perception of a three dimensional object is usually an active experience involving information on touch, texture, temperature and the movement and position of the hands and fingers in order to identify an object through touch alone... [27, p. 264]

The study's observations demonstrated that haptic elements were a common feature of archaeologists' sense-making.

Identifying Neolithic pottery is quite difficult. Feeling the texture is one good way to do it. I'll sometimes rub a piece against my cheek to feel it... (Morrigan,finds expert)

In writing about this for the site blog, the researcher made a joke about not yet seeing an archaeologist taste a find. Within 24 hours, the researcher had been emailed a journal article on the practice by a former member of the dig team. In addition, two finds experts admitted that they did occasionally use their tongue to determine the texture of an artefact - but they had refrained from doing so while being observed!

The multi-sensory nature of archaeological analysis was encapsulated for the researcher in the words always used by Alliquippa, the resident geologist at the Ness when briefing each new group of students. Alliquippa's expertise had led directly to the identification of a hitherto unrecognised type of archaeological artefact: unworked stones, often large river-washed pebbles, brought by Neolithic people from other parts of the Orkney islands or the Scottish mainland to the Ness site, presumably for ritual purposes. In briefing students, Alliquippa would say:

If it feels heavy...

If it feels light...

If it feels smooth...

If it looks darker...

If it looks lighter...

... Bring it to me! (Alliquippa, site geologist)

Participants' information practices were shown to be not merely cognitive but embodied [18]. The embodied practices demonstrated by the participants bring to mind Gherardi:

...the material body - the body that works - assumes shape and location within the set of practices that constitute the work setting. The knowledge acquired via the five senses is aesthetic, not mental. It often forms the basis for specific competences. Craft trades required trained bodies - ones, that is, which have incorporated an expertise. It is through the body that 'an eye' (or 'an ear' or 'a nose') for something is acquired, so that aesthetic knowledge ... also comprises the ability to develop a professional 'vision' in the broad sense. [9, p. 521]

The study's findings provide strong evidence to suggest that such embodied practices should not be seen as solely a characteristic of craft trades.

\subsection{Archaeology as Apprenticeship}

Haptic analysis was only one example of the embodied practices that archaeology students and volunteers working on the sites needed to acquire. Field archaeology involves a range of physical activities: some, such as lifting heavy stones or moving dirt to the spoil heap, are physically demanding, while others, such as uncovering and lifting a fragile artefact, require both dexterity and a delicate touch.

I prepared for volunteering here by reading lots of archaeology books. I realise now I should have prepared by going to the gym! (Eleanor, site volunteer)

The study therefore sought to gain an understanding of the practices by which those new to the field acquired the necessary embodied knowledge to safely and effectively perform the tasks expected of them. Both sites included in the study attracted students and volunteers from Europe and North America as well as the UK. The Ness site, in particular has an international reputation for the quality of the field schools it runs.

Working in the field is very different from learning about archaeology in the classroom. I bring my students here because Lugh [site director] and the team here put a lot of work into making sure they get the hands-on experience they need. (Tecumseh, archaeology professor) 
I think we need to recognise that a successful archaeologist needs a range of quite different skills. On the one hand, they need academic knowledge, to know the literature of the field. On the other hand, working in the field needs an entirely different set of skills ... While university lectures and tutorials are a good way to learn the academic side, they can't teach the practical skills needed in the field. (Eric Bloodaxe, archaeology professor)

Both site directors were very conscious of the importance of mentoring for this process, with groups of students and volunteers being allocated to work with trench supervisors and other team members with extensive field experience.

For a lot of these students, it's their first time in the field, so I'll have them work with some of our more experienced people. We're really lucky to have people like Frigg and Beyla, who are experienced commercial archaeologists giving up their holidays to work with us. They [the students] really find out what real archaeology is all about working with them! (Boudicca, site director)

Throughout the ethnographic fieldwork, the researcher observed numerous instances of experienced team members explicitly modelling embodied practices by demonstrating the correct way to use a trowel or to lift or clean a delicate artefact. Students and volunteers were often deliberated rotated so that they might learn from different senior team members recognised as possessing a particular expertise. Students were seen to model their own actions on those of the senior team members they worked with.

In observing the learning practices on the two sites, there were clear parallels with those described by Lloyd [18] in her studies of firefighters. More broadly, it was apparent that students and volunteers undertook a kind of apprenticeship, as described by Lave \& Wenger [27] in their work on situated learning. The concept of field archaeology as an apprenticeship was one that resonated with senior archaeologists the researcher spoke to:

I think it is a kind of apprenticeship... Students come to us with a theoretical knowledge of archaeology but being in the field requires a different set of skills. It's physical as well as mental. You can't really understand that until you start getting your hands dirty. ... The best way to learn is to get in the trenches with someone who knows what they're doing. (Boudicca, site director)

We're very fortunate here because all the senior people, the trench supervisors, the finds experts, all take that mentoring role very seriously. They go out of their way to show students how it's done. ... We do our best to turn them into real archaeologists! (Macbeth, finds expert)

The everyday discourse of team members also emphasised the importance of embodied practices to field archaeologists. Numerous stories and anecdotes shared with the researcher focused on the idea that a "real archaeologist gets down and dirty", "isn't afraid to get their hands dirty". One visiting TV presenter was received warmly as a 'real archaeologist' based on his previous field experience, while another academic visitor was described less approvingly by some team members as a "book archaeologist".

Team members' discourse about embodied skills as a defining characteristic of a 'real' field archaeologist strongly brings to mind Coupland and Gwynn's [17] argument that embodied practices can play a crucial role in defining the social identity of a community. The discourse also suggest that recognition by community members as possessing such skills was an important source of authority, of Foucault's pouvoir/savoir [11], in a field archaeological context.

Story-telling also played an important role in this mentoring process, with senior dig team members' discussions with students and volunteers being peppered with anecdotes and examples drawn from their previous field experience.

When Macbeth [finds expert] or Icarus [trench supervisor] talk about what we're doing, they'll often talk about how it's like something they've done last season or on another dig somewhere else. That helps me understand why we're doing something that might otherwise seem boring ... It also makes me realise I'm lucky to have the chance to work with people with so much experience. (Artemis, archaeology student)

Story-telling thus not only served a useful educational role in contextualising practices for newer team members: it also had the effect of enhancing the speaker's discursive authority in this context.

\subsection{Affect \& Informal Knowledge Sharing}

The sharing of embodied knowledge was not confined to mentor-student contexts. More experienced team members also demonstrated a strong interest in both refining their skills and in sharing their own expertise with other team members. 
One of the reasons I love coming here and keep coming back is how much I learn myself. Macbeth [finds expert] came over to help me lift that grooveware pot ... it was like watching a surgeon at work. That kind of thing makes me a better archaeologist. (Heimdall, trench supervisor)

As someone who works in commercial archaeology, coming here and working on a large academic dig provides me with a great opportunity to learn, to find out about new developments and new techniques. Working with uni-based archaeologists and with people from around the world is a great learning opportunity for me. (Frigg, commercial archaeologist)

Despite the rather hierarchical structure of work on the sites, an informal atmosphere and a strong sense of camaraderie was evident amongst team members. This warm social environment no doubt fostered informal knowledge sharing.

When I first came here I was a bit intimidated. Everyone knew more than me! But people are so friendly and helpful. They really do want to help you. ... I think what brings people together is that shared passion. (Minerva, site volunteer)

I think this is one of the friendliest digs I've ever worked on. That's why we keep coming back year after year. And I think that makes it much easier to go up to someone and say "What are you doing there?" or to go up to someone at tea break and have a talk to them about their specialist area. It makes it easy to pick people's brains! (Hereward, archaeologist)

Humour was a frequent feature of interactions between team members, including a range of in-jokes, such as ironic cries of "Treasure!" This convivial atmosphere, along with the genuine shared passion of team members for their field and the sites, clearly facilitated informal information sharing, as well as keeping team members motivated during what was often hard physical work in highly changeable Orcadian weather conditions.

\subsection{Drawing as an Embodied Practice}

Another embodied information practice whose ubiquity was perhaps slightly surprising in an age where digital photography, scanning and GPS logging are everyday tools in contemporary archaeological practice was drawing. From the site director, through team members recognised for their skill in drawing site and trench maps, through to students on their first dig, drawing was a practice that the researcher observed on a daily basis.

The drawing practices observed took a variety of forms. Some were highly structured, involving the carefully gridsquared maps or cross sections of a trench or the site as a whole. Others were more informal, with many team members making drawings of artefacts or features as part of their personal dig journals.

When probed on why this particular form of information construction continued to be so prevalent, participants provided a variety of explanations. These ranged from the practical:

The thing is that with a drawing, you can focus on particular details that are significant. You can't really do that with a photograph

- there's too much there. The details get in the way. A 3D scan has the same problem, really. (Icarus, trench supervisor)

To the traditional:

It's something that archaeologists have always done. I think it's important that students learn how to record in the traditional way, not just how to use the technology. (Tecumseh, archaeology professor)

However, the reason most frequently given by participants was that drawing allowed them to develop a deeper understanding of the area they were working in:

I don't think you really understand your trench until you've sat down and drawn it. (Hereward, archaeologist)

When I'm trying to get my head around the stratigraphy of my trench, how the different layers in different parts of the trench relate to one another, I find that drawing it helps me get a much clearer picture of how they fit together. (Beyla, trench supervisor)

These comments and the many others like them suggest that for the participants drawing is an information practice which allows them to think about the site of their work in a different way and consequently develop a deeper understanding. While information researchers have been interested in the nature of documents since the $19^{\text {th }}$ century and their role in shaping the cognitive processes of readers has been a major focus of information behaviour research since the 1970s, these findings suggest that there are aspects of the relationship between documents and their creators that remain under-researched in our field. 


\subsection{Recording Finds}

Drawing was clearly not the only, or even the principal, information practice employed by team members. Geophysical surveys using ground-penetrating radar and allied technologies play an essential role in understanding sites and developing excavation strategies. During the digs, the researcher observed the position of every find being carefully logged using GPS-based technology. In addition, numerous digital photographs were taken and at the Ness of Brodgar, some use was made of 3D scanning technology to record the position of finds in the ground before they were fully excavated.

\subsection{Context and Find Sheets}

Despite the prevalence of these technologies, participants emphasised the central role played by more traditional methods of recording, such as context and find sheets:

It's really important that the students learn to fill in the find sheets in the right way because they form the basis for our records ... They're really what they'll use to work out what tests to be done back at the lab. (Morrigan, finds expert)

Chadwick has suggested that forms such as find and context sheets have increasingly become "tools of a new archaeological orthodoxy" [29,5] constraining the actions and creativity of those excavating sites. The study's findings do broadly support the notion that such forms act as 'boundary objects' [30] in defining archaeological information practices, particularly for less experienced team members:

If I'm not sure what I'm supposed to be recording about something, the sheets can be really helpful. They make sure I don't leave out something important! (Togidubnus, site volunteer)

Sometimes the find sheet can give you a clue about what people are interested in. So here, they have fields on the find sheet to record things like incised stone because that's what Freyja is doing her PhD on. So I suppose it makes me look out for that... (William Wallace, archaeology student)

However, they also parallel Yarrow [31] in suggesting that experienced team members in particular are adept at moving beyond the constraints and assumptions imposed by such forms:

The forms need to be pretty general - but you soon work out what's important and what's relevant. You know what you really need to fill in and what you can ignore. (Mary Stewart, archaeologist)

The researcher observed many of the same practices described by Yarrow, as selective use and omission of fields and using comments fields to provide extra detail. These recording instruments are, however, essentially object-oriented, describing the particular context layer or artefact. They do not therefore directly record information about the process: the practices by which team members made sense of their trench or find. As a consequence, the multi-sensory practices described in this study remain a largely 'invisible' practice, at least in terms of being incorporated into the excavation's official documentation.

\subsubsection{Dig Diaries, Blogging and Social Media}

This is not to say that team members do not find other media and methods to provide a richer picture of their practices and experience such as personal dig diaries, personal notebooks/drawings, site blogs and social media:

A few of us [students] are blogging about the field work, what we're doing, what we're learning ... the cool stuff, the fun stuff... It's kind of cool to read about what the others are writing and compare it to your own experience. (Joan of Arc, student)

I've always kept a dig diary. I'll sit down and make notes for myself whenever I can. ... I like to include little sketches as well ...

I like to go back and look at it at the end of the season. It helps me put the pieces together... (Hereward, archaeologist)

This kind of material has tended to be informal and not included amongst an excavation's official records. However, archaeological teams are increasingly recognising the important role that such material can play in engaging and maintaining public interest in their work:

We all know that the site report, what we write for the archaeology journals, has to be written in quite a dry way... It's going to go over the heads of most people. ... They want to hear the stories, find out about the people. That's what the site blog allows us to do. (Lugh, site director) 
Both sites, for example, maintained a daily dig diary on the Orkneyjar website. This provided daily news on the progress of the dig as well as also including each day a brief piece written by one of the dig team about their work and experiences on the site. These were written by students and volunteers, as well as more senior members of the dig team - including the author! Many visitors to both sites mentioned to the researcher following the dig via these dig diaries and all those taking tours of the Ness site were given cards with its URL so that they might continue learning about the site after their visit. The potential benefits of developing this kind of web presence may be seen in the fact that the Ness team was able to extend their excavation period in 2015 by four weeks, thanks largely to funds generated by the online American Friends of the Ness of Brodgar ${ }^{6}$. The virtual communities developed around archaeological and heritage sites are an area that warrants further investigation by information researchers.

Another area warranting attention from information researchers and professionals is the development of appropriate aggregation tools by which social media, blogs and other material relating to sites might be harvested and archived. This would allow the rich experiential material it records to be available to future researchers, curators and site visitors.

\section{Conclusion}

The findings of the present study are significant in a range of different contexts. The sense-making of field archaeologists begins a journey that continues through museum curatorial practices and ultimately leads to labels in exhibitions and records in digital repositories and collections. By gaining an understanding of how these practices begin, we provide a stronger basis for understanding how the meaning of archaeological artefacts and sites evolves and changes along the road from mud to museum.

In an organisational learning/knowledge management context, the study's findings about students and volunteers through a Lave and Wenger-like apprenticeship process raises important questions about many prevailing assumptions about the distinction between academic and craft learning. Further research in a range of other contexts, such as the medical and creative industries, would help develop our understanding in this area.

The findings also demonstrate the central role played by embodied information practices in this context. It is hoped that these findings, following on from earlier work by Lloyd [18][19] and the author [14][15][16], will convince other information researchers to consider the role of embodied practices in other contexts.

More generally in an information studies context, the study demonstrates how the application of social constructionist and practice-theoretical concepts can lead to a more holistic approach to understanding the complex inter-relationship of people, information and social context. The information practices perspective allows the researcher to look beyond the behaviour of individual information seekers and begin to understand the significant role of discursive, affective and embodied practices of both individuals and communities.

.Methodologically, the study offers one example of how the concerns of the 'information practices' might be empirically examined. Qualitative interviewing has long been a staple of information behaviour research as it is recognised as an effective means for researchers to engage with participants' stories, and through them, the discourses participants engage with. By incorporating ethnographic observation and on-the-spot interviewing, the researcher was able to gain different insights into the dig teams' practices and social interactions, their everyday lived social reality. Spending time on-site with the dig teams not only the afforded the researcher the opportunity to observe, but also to some extent share the everyday challenges and successes of team members. This shared experience no doubt promoted a greater understanding between the researcher and participants, enhancing both the research interviews and the participants' engagement with the analysis process.

The study thus represents the researcher's attempt to engage with the theoretical and methodological challenges of the emerging 'information practices' umbrella discourse [1, p. 109]. The further development of this approach offers many opportunities to expand and enrich future information research.

\section{Notes}

1. http://www.orca.uhi.ac.uk/

2. http://www.orkneyjar.com/archaeology/thecairns/

3. http://www.orkneyjar.com/archaeology/nessofbrodgar/

4. http://ngm.nationalgeographic.com/2014/08/neolithic-orkney/brodgar-graphic

5. Participants were invited to choose their own pseudonym using the name of an historic or mythological character

6. https://www.facebook.com/AmericanFriendsNessBrodgar/info/ 


\section{Acknowledgements}

This article is based on a paper originally presented at the information: interactions and impact (i3) conference at Robert Gordon University, 23-26 June 2015. The author wishes to thank the anonymous reviewers for their constructive feedback.

\section{Funding}

Funding for the fieldwork for this study was provided by a research development grant from the Faculty of Arts and Social Sciences, University of Technology Sydney.

\section{References}

[1] Savolainen, R. Information Behaviour and Information Practice: Reviewing the 'Umbrella Concepts' of Information-Seeking Studies. Library Quarterly 2007. 77 (2), pp.109-132.

[2] Pryor, F. Britain AD: a quest for Arthur, England and the Anglo-Saxons. HarperCollins 2005.

[3] Lund, N.W. Document theory. Annual Review of Information Science and Technology 2009. vol. 43, no. 1, pp.1-55.

[4] Briet, S. What is documentation? English translation of the classic French text. Lanham, MD, Scarecrow 2006.

[5] Huvila, I. The politics of boundary objects: hegemonic interventions and the making of a document, Journal of the American Society for information Science and Technology 2011, 62 120, pp. 2528-39.

[6] Berger, P.L. and Luckmann, T. The Social Construction of Reality. A Treatise in the Sociology of Knowledge, Allen Lane, London 1967.

[7] Gherardi, S. Practice-Based Theorizing on Learning and Knowing in Organizations. Organization 2000, 7(2), pp. $211-23$.

[8] Nicolini, D. Practice theory, work, organization. Oxford: Oxford University Press 2013.

[9] Gherardi, S. Situated Knowledge and Situated Action: What do Practice-based studies Promise? In: Barry D. and Hansen H (eds) The Sage Handbook of New Approaches in Management and Organization, Sage Publications Ltd, Thousand Oaks, CA, 2008, 516-527.

[10] Dervin, B., Foreman-Wernet, L. et al Sense-Making Methodology reader: Selected writings of Brenda Dervin. Cresskill, NJ: Hampton Press 2003.

[11] Foucault, M. Power/Knowledge: Selected Interviews and Other Writings 1972-1977 London: Harvester Press 1980.

[12] Fairclough, N. Analysing discourse: textual analysis for social research London; New York: Routledge 2003.

[13] Dervin, B. On studying information seeking and use methodologically: The implications of connecting metatheory to method. Information Processing \& Management 1999, 35, pp. 727-750.

[14] Olsson, M.. The play's the thing: theater professionals make sense of Shakespeare. Library \& Information Science Research 2010, 32(4), pp. 272-280.

[15] Olsson, M. All the World's a Stage - the Information Practices and Sense-Making of Theatre Professionals. Libri 2010, 60, pp. 241-252.

[16] Olsson, M. Gently to hear, kindly to judge: the affective information practices of theatre professionals and journalists. Information Research 2013, 18(3) paper C22. http://InformationR.net/ir/18-3/colis/paperC22.html (accessed July 2015)

[17] Coupland, J. and Gwyn, R. Discourse, the body, and identity 2003.

[18] Lloyd, A. Learning to Put Out the Red Stuff: Becoming Information Literate through Discursive Practice. Library Quarterly 2007, 77(2), 181-198.

[19] Lloyd, A. Framing information literacy as information practice: Site ontology and practice theory. Journal of Documentation 2010, 66(2), 245-268.

[20] Geertz, C. The Interpretation of Culture. Basic Books 1977.

[21] Bryman, A. Social Research Methods, 4th Edition, Oxford UK, Oxford University Press 2008.

[22] Seidman, I. E. Interviewing as qualitative research: a guide for researchers in education and the social sciences. New York: Teachers College Press 1991.

[23] Miles, M. B., and Huberman, M. A. Qualitative Data Analysis (2nd ed.). Thousand Oaks: Sage 1994.

[24] Kvale, S. Interviews. An introduction to qualitative research interviewing. Thousand Oaks: Sage Publications 1996.

[25] Phillips, N., \& Hardy, C. Discourse analysis. Investigating processes of social construction. Thousand Oaks: Sage 2002.

[26] Alvesson, M. and Kärreman, D. Varieties of discourse: On the study of organizations through discourse analysis. Human Relations 2000, 53(9), pp, 1125-1149.

[27] MacGregor, G. Making sense of the past in the present: a sensory analysis of carved stone balls. World archaeology 1999, 31(2), pp. 258-71.

[28] Lave, J., \& Wenger, E. Situated learning: Legitimate peripheral participation. Cambridge: Cambridge University Press 1991.

[29] Chadwick, A. (1998). Archaeology at the Edge of Chaos: Further towards reflexive excavation methods. Assemblage Online http://www.assemblage.group.shef.ac.uk/3/3chad.htm (accessed July 2015)

[30] Brown, J.S. \& Duguid, P. The social life of documents. First Monday 19961 (1). 
[31] Yarrow, T. In context: meaning, materiality and agency in the process of archaeological recording. Material Agency 2008, Springer, 121-37. 